\section{A daunting proposition}

\section{San Francisco}

ON 6 November, Californian voters will be asked to decide the fate of 'Big Green', a complex environmental initiative that is to its supporters a model for an aggressive environmental policy, but which opponents say will produce uncertain benefits at enormous cost.

Both sides last week issued reports on one of the initiative's central requirements, an enforced reduction in carbon dioxide emission of 40 per cent by 2010 , and their conclusions are staggeringly different. Supporters say Big Green will save a total of $\$ 87,000$ million by 2010 , while opponents claim it will cost California $\$ 17,000$ million annually.

Proposition 128, may stand or fall according to voters' perceptions of its economic impact rather than their environmental or political consciences. It specifies carbon dioxide reductions, but does not say how they should be achieved, and by painting different pictures of what Proposition 128 would demand, each side has come up with detailed projections, powerful figures and grossly different pictures of what the changes would mean to the public.

In California especially, reducing carbon dioxide emissions means persuading drivers to use their cars less, or at least to use them more efficiently. Economists at the Natural Resources Defense Council (NRDC), which prepared the analysis supporting Proposition 128, argue that by offering rebates to buyers of fuel-efficient automobiles (perhaps paid for by buyers of gas-guzzlers), by reducing the carbon concentration of gasoline and by augmenting public transport systems to decrease the miles travelled per car by 20 per cent over the next 20 years, $\$ 9,700$ million could be saved by 2000 .

But Spectrum Economics of San Francisco, which prepared a report for the opposition, claims that a gasoline tax would be needed to discourage driving, and that to meet the required reductions, gas prices would rise by up to 70 cents per gallon by 2000 and twice that by 2010 . Cars are not replaced often enough to change the average fuel efficiency of the California fleet except slowly, and masstransit systems are costly, according to Steve Moss, principal author of the Spectrum report.

Electricity generation and use is another contentious issue. Chris Calwell, principal author of the NRDC report, believes that by improving the energy efficiency of lighting, appliances and buildings in general, enough energy can be saved to meet the emissions reductions required by 2000 . Increased use of renewable energy sources such as solar, wind and geothermal power will then meet the 2010 goal. The Spectrum report disagrees: even after implementing conservation measures, it says, an electricity rate increase of 20 per cent would be needed by 2000 , largely to fund conversion of coal-burning power plants to natural gas use.

The different economic projections reflect in part differences in the extent of the consequences the two groups consider. The NRDC report, for example, estimates savings accruing from reduced damage to air quality, ecosystems and human health at $\$ 50,000$ million over the next 20 years. Consumers, however, may find it hard to see long-term indirect benefits, but easy to fear hefty increases in electricity and gasoline prices, particularly during the present turmoil in the Middle East. Those concerns may sway voters on 6 November. Recent polls have shown opposition to Proposition 128 mounting, and it is now nearly equal to the level of support.

Proposition 128 is an enormously complex conglomerate of environmental measures that will test the voters' stamina and understanding. In addition to its carbon dioxide emissions limits, it would, among other things, phase out the sale and manufacture of products containing chlorofluorocarbons, require developers to plant a tree for every 500 square feet of new construction, provide $\$ 200$ million to protect the state's redwood forests, permanently ban new oil and gas drilling within three miles of the coast, establish a \$500-million oil-spill prevention and cleanup fund, phase out 19 pesticides known to cause cancer or reproductive harm and establish a post for an elected state Environmental Advocate to oversee and enforce environmental laws. The state's nonpartisan Legislative Analyst's Office estimates that administrative costs alone for the proposition will reach $\$ 90$ million annually.

The environmental policy bestowed on California may be decided ultimately by the comparison-shopping abilities of voters, who have several related initiatives to choose from. Agricultural interests have responded to the pesticide portion of 128 by introducing a competing initiative with less restrictive rules, and environmentalists and the timber industry have squared off with two competing forestry propositions.

As election day approaches, Proposition 128's supporters continue to hail it as an opportunity to clean up air, water and food supplies. Detractors hope to convince voters that the measure is a poorly constructed amalgam of legislation that would strangle the state's economy. "People are wary of something that contains so much", says Scott Macdonald of the No-on-128 campaign.

Elizabeth Schaefer

\section{The French used to have a wôrd for it}

Paris

In a move to improve standards of literacy that could yet end in tears, the French are to strip away some of their beloved accents.

A major casualty of a language reform that began with a plea for spelling 'rectification' from the Prime Minister, Michel Rocard, and ended with recommendations* ratifed by the august Académie Française, is the circumflex. The 'little hat', beloved of schoolchildren and the bane of wordprocessors, will now no longer be required for the vowels ' $i$ ' and 'u'.

Août, the month when Paris empties for the summer holidays, will now be a bare-headed aout. And scientists will be in for surprises too. (Since they are not supposed to be able to spell, perhaps it will make little difference.) We now have croitre (to grow), boite (a box, as in boite noire), gout (taste), chaine (as in chaine alimentaire or food chain), ile, maitre, fraiche, voute and bruler.

Some of the academy's proposals are so subtle that even the average Frenchman may neither recognize the problem nor understand the solution, but others are more radical. The hyphen is removed, whenever possible. All those Latin words beginning with extra-, intra-, ultra-, infraand supra- grow shorter, making infrarouge, supraconducteur and ultravirus. Ancient gallic words such as covergirl, striptease, lockout and cowboy lose their hyphens, as do apriori, exvoto, kilowattheure, monoatomique, spatiotemporel and typhobacillose.

But for amateurs of the doublebarrelled, all is not lost. Aide-mémoire, serre-livre (bookend), ramasse-miette (a device for picking up crumbs) and many others keep their umbilical link.

Accents are not being totally abolished. A few have even been added, especially to foreign words - a lexical equivalent of immigration papers: artéfact, duodénum, placébo, édelweiss, pénalty and révolver, for example. Finally, "diverse anomalies" are mopped up by the "look and say" principle: chariot becomes charriot, oignon (as in soup) becomes ognon, relais (as in routiers) becomes relai and skunks (skunk) becomes sconse. While the education minister, Lionel Jospin, hopes that the 'rectifications' will improve standards of spelling, the simplifications could also help to stop the French language being overrun by 'anglais'.

In any case, the ministry expects the new rules to percolate into use "within a year". But signs of 'la résistance' are already emerging in some circles. Peter Coles

* Les rectifications de l'orthographe. Conseil supérieur de la langue française. Hôtel Matignon. 19 June 1990. 